\title{
Production Process of an Eco-Friendly One-Part Alkali-Activated Binder
}

\author{
Rodrigo H. Geraldo ${ }^{a, b}$ (1), Jardel P. Gonçalves ${ }^{c}$, Gladis Camarini ${ }^{a, d} *$ (]) \\ ${ }^{a}$ Universidade Estadual de Campinas (UNICAMP), Faculdade de Engenharia Civil, Arquitetura e \\ Urbanismo, Rua Saturnino de Brito, 224, 13083-889, Campinas, SP, Brasil. \\ ${ }^{b}$ Centro Universitário FACENS, Rodovia Senador José Ermirio de Moraes, 1425, Castelinho km 1,5, \\ Alto da Boa Vista, 18087-125, Sorocaba, SP, Brasil. \\ ${ }^{c}$ Universidade Federal da Bahia, Escola Politécnica, Centro Interdisciplinar de Energia e Ambiente \\ (CIENAM), Rua Aristides Novis, 02, Campus da Federação, 40210-630 Salvador, BA, Brasil. \\ ${ }^{d}$ Centro Universitário do Sul de Minas (UNIS-MG), Avenida Alzira Barra Gazzola, 650, Bairro \\ Aeroporto, 37031-099, Varginha, MG, Brasil.
}

Received: August 28, 2021; Revised: October 19, 2021; Accepted: November 04, 2021

\begin{abstract}
One-part alkali-activated binder $(\mathrm{AAB})$ is a product with lower environmental impact than Portland cement, and can be a feasible commercial alternative. The main objective of this study was to propose and test a method of obtaining one-part $\mathrm{AAB}$ with metakaolin and an alternative powder sodium silicate from rice husk ash (RHA). To evaluate the $\mathrm{AAB}$ properties, mortars were produced with different $\mathrm{SiO}_{2} / \mathrm{Al}_{2} \mathrm{O}_{3}$ molar ratios $(2.7,3.1$, and 3.3), and tests were conducted to characterize the binder. The results indicated that the process was efficient in generating a non-crystalline sodium silicate powdered material. With high $\mathrm{SiO}_{2} / \mathrm{Al}_{2} \mathrm{O}_{3}$ molar ratio the mortars achieved high compressive strength and it increased with age, had low permeability, and capillary water absorption. Compressive strength results varied from $6 \mathrm{MPa}$ to $12 \mathrm{MPa}$ at 28 days, indicating the possibility of using the proposed method for one-part $\mathrm{AAB}$ production. $\mathrm{AAB}$ produced can be applied in different building materials.
\end{abstract}

Keywords: One-part alkali-activated binder, production process, cement, alternative binder, cleaner production, sustainability.

\section{Introduction}

Alkali-activated binder (AAB) can be considered one of the breakthroughs in concrete technology of the last century ${ }^{1}$. $\mathrm{AAB}$ is an alternative to Portland cement (PC), and it is formed by a chemical reaction between an alkali-activator with an aluminosilicate precursor ${ }^{2}$.

The environmental benefits of $\mathrm{AAB}$ have driven the interest in this cement. AAB production does not demand high calcination temperatures and the chemical reaction does not release $\mathrm{CO}_{2}^{3,4}$. According to Carreño-Gallardo et al. ${ }^{5}$, the replacement of $\mathrm{PC}$ by $\mathrm{AAB}$ can provide a reduction of up to 1480 million tons of $\mathrm{CO}_{2}$ per year. Accordingly, the reduction of $\mathrm{CO}_{2}$ emissions when compared to $\mathrm{PC}$ is one of the main facts that direct the researchers to pay attention to $\mathrm{AAB}^{6}$.

There are two methods to AAB production. The twopart mixing is more usual in the literature, but the one-part mixing is a recent proposal of growing interest because of the commercialization feasibility and facility of using ${ }^{7,8}$. In two-part mixing, the aluminosilicate precursor is a solid material, and the alkali-activator is an aqueous solution. These two parts are mixed to form the AAB. Differently, in one-part $\mathrm{AAB}$ the aluminosilicate source and the alkali activator are powders. One-part AAB is used in the same way of conventional PC: the dry materials are mixed with water, starting the binding reaction ${ }^{7-10}$.

*e-mail: gcamarini@gmail.com
The discovery of one-part $\mathrm{AAB}$ was a significant event in the development of eco-friendly cement ${ }^{11}$. The one-part AAB does not need storage, management, and use of highly corrosive alkali-solutions in the worksite, which are very dangerous to the workers involved. This favors the commercialization and application of $\mathrm{AAB}$ in civil construction activities ${ }^{1,12,13}$.

One-part AAB made with anhydrous sodium metasilicate as activator presented high compressive strength; however, the production of this chemical product has environmental impacts $^{12,14,15}$. The extra energy necessary to produce the solid activators makes one-part AAB more environmentally impacting than a two-part binder ${ }^{16}$.

Within this scenario, researches have been conducted on alternative activators. Abdel-Gawwad et al. ${ }^{17}$ proposed a new user-friendly activator powder obtained by thermal treatment at $60^{\circ} \mathrm{C}$ of a mixture of sodium hydroxide and ethylene glycol. Granulated blast-furnace slag or slag-lead bearing sludge was mixed with the activator to originate one-part AAB. Pastes achieved considerable mechanical strength, with one-part AAB presenting a compressive strength $157 \%$ higher than two-part AAB at 180 days. In another research, Ma et al. ${ }^{15}$ evaluated the partial replacement of sodium silicate anhydrous by sodium sulfate, aiming to achieve a cleaner one-part AAB. They found the use of sodium sulfate generated material with compressive strength higher than $15 \mathrm{MPa}$ at 1 day and reduced the carbon footprint of AAB. Samarakoon et al. ${ }^{18}$ obtained an alternative activator to commercial sodium silicate by mixing soda-lime glass 
powder and sodium hydroxide. They tested the solid activator with fly ash/ground granulated blast-furnace slag precursors in mortar production, and the results indicated compressive strength higher than $30 \mathrm{MPa}$ at 28 days. The alternative solid activator showed to be cheaper and more environmentally friendly than commercial options.

The use of agro-industrial wastes, such as rice husk ash (RHA) due to the high volume generated and high reactive silica content, has a growing interest recently ${ }^{19-21}$. RHA has been applied in civil construction as supplementary cementitious material, and it has also been used to obtain alternative sodium silicate solutions to AAB production ${ }^{19,22-32}$. Commercial sodium silicate has a high carbon footprint and the use of alternative dissolved silica sources is important in environmental aspects ${ }^{21}$. The activators are considered as the main problem related to $\mathrm{AAB}$ production because they are produced using expensive and polluting processes ${ }^{33}$.

In this study, an alternative sodium silicate powder from RHA was proposed to make one-part AAB. The research aimed to test an innovative production method to produce a binder with cleaner production.

\section{Materials and Methods}

\subsection{Materials}

In the present investigation, it was used the precursor materials to make the AAB (metakaolin - MK, rice husk ash - RHA, and sodium hydroxide $-\mathrm{NaOH}$ ) and natural river quartz sand to make the mortar to evaluate the $\mathrm{AAB}$ properties to building components.

Metakaolin (MK = "HP ultra" from Metacaulim do Brasil Indústria e Comércio Ltd.) and rice husk ash (RHA = "Silcca Nobre" from Sílica Verde do Arroz Ltd.) were the aluminosilicate sources. The two solid precursors are commercial products, and they were employed without any additional processing.
Chemical composition, physical characteristics, and particle size distribution of the MK and RHA are shown in Table 1 and Figure 1. The chemical compositions were determined using X-ray fluorescence (XRF) (equipment: Bruker FRX S8-Tiger). Particle size distribution was carried out with a laser diffraction particle size analyzer (Malvern Mastersizer 3000).

$\mathrm{MK}$ is mainly composed of $\mathrm{SiO}_{2}$ and $\mathrm{Al}_{2} \mathrm{O}_{3}$, which represent more than $90 \%$ of the total composition. According to Poon et al. ${ }^{34}$, MK is typically composed of $50-55 \% \mathrm{SiO}_{2}$ and $40-45 \% \mathrm{Al}_{2} \mathrm{O}_{3} \cdot \mathrm{TiO}_{2}$ is a common impurity presented in MK and the content found was similar to other researches ${ }^{35,36}$. Considering the physical properties, Rashad ${ }^{37}$ presented that typical values of bulk density and specific mass of MK are $2600 \mathrm{~kg} / \mathrm{m}^{3}$ and $300-400 \mathrm{~kg} / \mathrm{m}^{3}$, respectively. The obtained results indicated that $\mathrm{MK}$ used in the present study is slightly denser. The high content of $\mathrm{SiO}_{2}$ in $\mathrm{RHA}(>90 \%)$ was also observed by Tong et al. $^{32}$ and indicates the feasibility of

Table 1. Chemical composition and physical properties of metakaolin (MK) and rice husk ash (RHA).

\begin{tabular}{|c|c|c|}
\hline Oxides (mass \%) & MK & RHA \\
\hline $\mathrm{SiO}_{2}$ & 49.36 & 93.19 \\
\hline $\mathrm{Al}_{2} \mathrm{O}_{3}$ & 41.07 & 1.27 \\
\hline $\mathrm{K}_{2} \mathrm{O}$ & 2.45 & 1.51 \\
\hline $\mathrm{Fe}_{2} \mathrm{O}_{3}$ & 2.08 & 0.05 \\
\hline $\mathrm{TiO}_{2}$ & 1.40 & - \\
\hline $\mathrm{MgO}$ & 0.82 & 0.33 \\
\hline $\mathrm{CaO}$ & 0.07 & 0.58 \\
\hline Loss on ignition & 2.45 & 2.08 \\
\hline Others & 0.30 & 0.99 \\
\hline \multicolumn{3}{|l|}{ Physical properties } \\
\hline Bulk density $\left(\mathrm{kg} / \mathrm{m}^{3}\right)$ & 439 & 479 \\
\hline Specific mass $\left(\mathrm{kg} / \mathrm{m}^{3}\right)$ & 2775 & 2388 \\
\hline Specific surface area - BET $\left(\mathrm{m}^{2} / \mathrm{g}\right)$ & 21.71 & 15.37 \\
\hline Mean particle diameter $(\mu \mathrm{m})$ & 11.32 & 13.83 \\
\hline
\end{tabular}
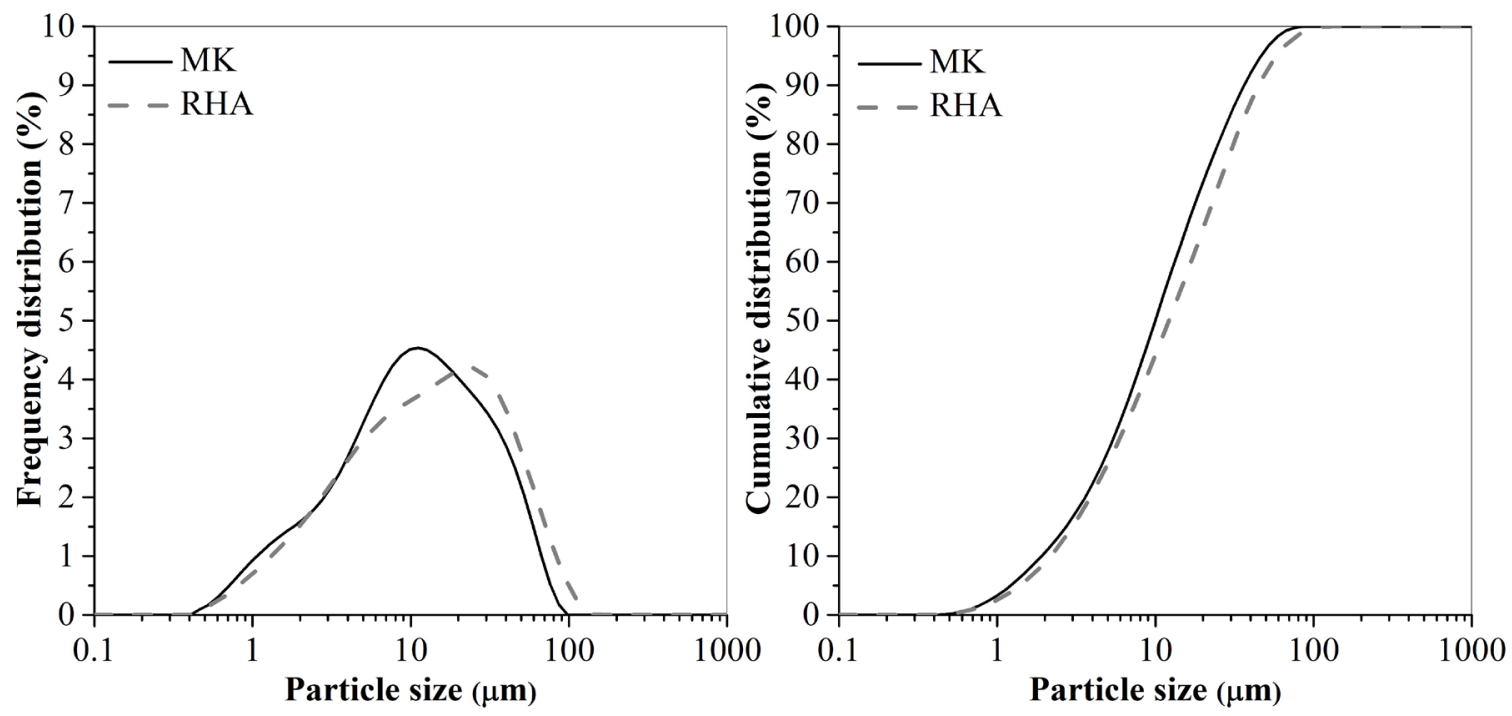

Figure 1. Frequency (a) and cumulative (b) distribution of the solid precursor. 

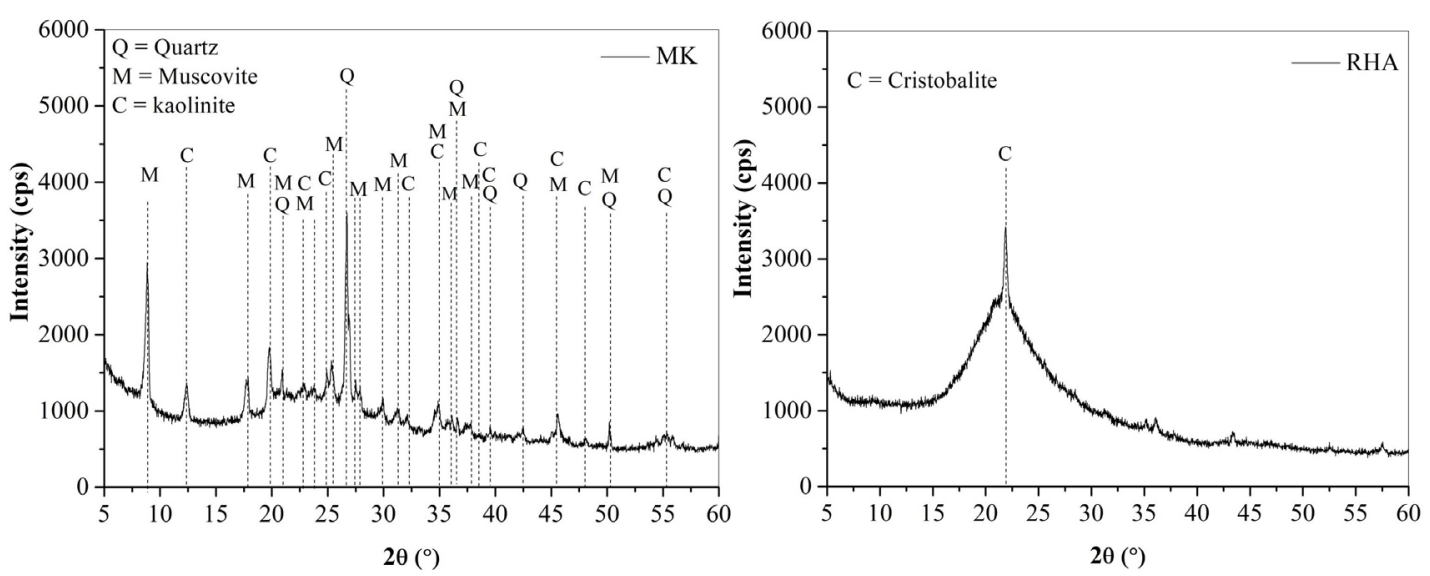

Figure 2. XRD patterns of MK (a) and RHA (b).

Table 2. Mix design (in weight).

\begin{tabular}{|c|c|c|c|c|c|c|c|c|c|}
\hline \multirow[b]{2}{*}{ Sample } & \multicolumn{4}{|c|}{ Molar ratio $(\mathrm{m} / \mathrm{m})$} & \multirow[b]{2}{*}{$\operatorname{APSS}^{2}(\mathrm{~g})$} & \multirow[b]{2}{*}{ MK (g) } & \multirow[b]{2}{*}{$\mathrm{NaOH}^{1}(\mathrm{~g})$} & \multirow[b]{2}{*}{$\mathrm{RHA}^{1}(\mathrm{~g})$} & \multirow[b]{2}{*}{ Sand $(\mathrm{g})$} \\
\hline & $\mathrm{SiO}_{2} / \mathrm{Al}_{2} \mathrm{O}_{3}$ & $\mathrm{Na}_{2} \mathrm{O} / \mathrm{SiO}_{2}$ & $\mathrm{Na}_{2} \mathrm{O} / \mathrm{Al}_{2} \mathrm{O}_{3}$ & $\mathrm{H}_{2} \mathrm{O} / \mathrm{Na}_{2} \mathrm{O}$ & & & & & \\
\hline A_2.7 & 2.7 & 0.1 & 0.6 & 16 & 30.7 & 91.3 & 8.0 & - & 244.0 \\
\hline B_3.1 & 3.1 & 0.2 & 0.6 & 16 & 42.0 & 80.0 & - & - & 244.0 \\
\hline C_3.3 & 3.3 & 0.2 & 0.6 & 16 & 42.0 & 80.0 & - & 3.6 & 244.0 \\
\hline
\end{tabular}

${ }^{1}$ Additional material used to adjust molar ratio. ${ }^{2}$ Alternative powder sodium silicate.

using it as a silica source, which tends to be reactive and suitable to $\mathrm{AAB}$ production ${ }^{38}$.

$\mathrm{X}$-ray diffraction (XRD) patterns of MK and RHA are shown in Figure 2. Equipment Bruker - S8 x-ray diffractometer with $\mathrm{CuK} \alpha$ radiation at $40 \mathrm{kV}$ and $40 \mathrm{~mA}$, from $5-60^{\circ} 2 \theta$ by scanning at $0.02^{\circ} \mathrm{seg}^{-1}$ was employed for XRD measurements. The identification of phases was carried out with X'Pert HighScore Plus version 3.0.5 and GSAS II version 3913 software. Inorganic Crystal Structure Database (ICSD) and Crystallography Open Database (COD) were used to identify the crystalline peaks.

XRD patterns indicate the mineral composition of MK (Figure 2a) is kaolinite $\left(\mathrm{Al}_{2} \mathrm{O}_{3} \cdot 2 \mathrm{SiO}_{2} \cdot 2 \mathrm{H}_{2} \mathrm{O}, \mathrm{COD}\right.$ ID: 9009234), muscovite ( $\mathrm{KAl}_{3} \mathrm{Si}_{3} \mathrm{O}_{10}(\mathrm{OH})_{2}, \mathrm{COD}$ ID: 9005014), and quartz $\left(\mathrm{SiO}_{2}\right.$, ICSD PDF: 01-085-0457). The range between $18^{\circ}$ and $35^{\circ} 2 \theta$ is related to non-crystalline phases with some peaks attributed to impurities as quartz ${ }^{23}$. RHA (Figure $2 \mathrm{~b}$ ) had a peak at $21.8^{\circ} 2 \theta$ attributed to cristobalite $\left(\mathrm{SiO}_{2}, \mathrm{COD}\right.$ ID: 9008225), a quartz polymorph formed during combustion ${ }^{28}$.

Sodium hydroxide $(\mathrm{NaOH})$ in flakes (Unipar Carbocloro S.A., $97.5 \%$ purity) was employed as activator, and water from the municipal supply was used for its dissolution.

Natural river quartz sand locally available was used as fine aggregate with specific mass of $2609 \mathrm{~kg} / \mathrm{m}^{3}$, bulk density of $1890 \mathrm{~kg} / \mathrm{m}^{3}$, fineness modulus of 2.38 , and maximum particle size of $2.4 \mathrm{~mm}$. Figure 3 shows the particle size distribution of the sand.

\subsection{Mortars: mix design, production, and curing method}

The mortar mix proportions are presented in Table 2.

The theoretical $\mathrm{SiO}_{2} / \mathrm{Al}_{2} \mathrm{O}_{3}$ molar ratio was varied to compare the influence of chemical composition on the

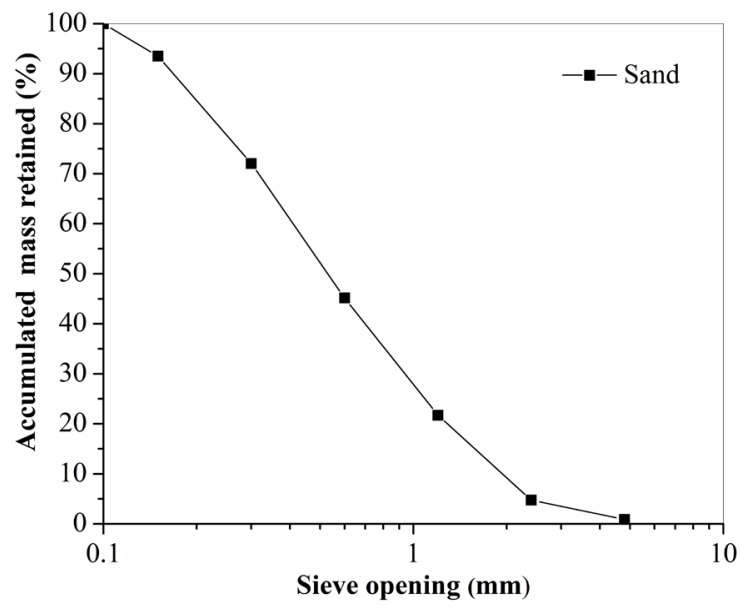

Figure 3. Particle size distribution of sand.

properties of one-part $\mathrm{AAB}$. In the literature, one-part $\mathrm{AAB}$ has been produced with $\mathrm{SiO}_{2} / \mathrm{Al}_{2} \mathrm{O}_{3}$ molar ratios ranging between $0.75-6.02^{8}$. In the present study, $\mathrm{SiO}_{2} / \mathrm{Al}_{2} \mathrm{O}_{3}$ molar ratios of 2.7, 3.1, and 3.3 (considering total solubility of raw materials) were used. The range employed was close to 3.0, considering the results of Bernal et al. ${ }^{25}$, which used MK and RHA to produce $\mathrm{AAB} . \mathrm{Na}_{2} \mathrm{O} / \mathrm{Al}_{2} \mathrm{O}_{3}$ and $\mathrm{H}_{2} \mathrm{O} / \mathrm{Na}_{2} \mathrm{O}$ molar ratios were kept constant in all the specimens by using extra $\mathrm{NaOH}$ or RHA in some mixtures to adjust the initial chemical composition. The binder/sand ratio was equal to 1:2.

To prepare the mortars, the solid one-part $\mathrm{AAB}$ and sand were put in a mechanical mixer (equipment: Perfecta; capacity: 20 L) for $2 \mathrm{~min}$ at slow speed until homogenization. Thereafter, water was gradually put in the mixture followed 
by continuous mixing (medium speed) for more $5 \mathrm{~min}$. The homogenized fresh mortar was immediately transferred to the molds, which were subjected to vibration (vibrating table) for $1 \mathrm{~min}$ to eliminate the entrapped air.

After casting, the molds were placed in a laboratory room with temperature of $25^{\circ} \mathrm{C} \pm 2{ }^{\circ} \mathrm{C}$ and relative humidity of $60 \% \pm 5 \%$. The specimens were demolded after 3 days of curing and stored in a sealed container in laboratory conditions until testing

\subsection{Methods}

\subsubsection{Thermogravimetry (TG), derivative thermogravimetry (DTG), and differential thermal analysis (DTA)}

Thermal analysis (TG/DTG/DTA) was carried out in a DTG 60H Shimadzu simultaneous TG/DTA apparatus using about $10 \mathrm{~g}$ of the sample in a platinum crucible. The heating rate of $10^{\circ} \mathrm{C} \mathrm{min}{ }^{-1}$ was used from $25^{\circ} \mathrm{C}$ to $1000{ }^{\circ} \mathrm{C}$ under a nitrogen flow of $50 \mathrm{~mL} \mathrm{~min}$.

\subsubsection{Specific mass, bulk density, and $p H$}

Specific mass (Le Chatelier flask) and bulk density of the powders were determined by adapting Brazilian Standards NBR $16605^{39}$ used for PC and NBR $12127^{40}$ used for gypsum plaster.

The $\mathrm{pH}$ of the powdered materials was estimated employing the method described to determine soil $\mathrm{pH}^{41}$. A $10 \mathrm{~mL}$ sample was mixed with $25 \mathrm{~mL}$ of distilled water. The mixture remained to stand for $1 \mathrm{~h}$, before determining the $\mathrm{pH}$ (equipment: Thermo Orion 410).

\subsubsection{Flow and heat release}

A flow table test was used to determine the workability of the mortars. The test was made following NBR $13276^{42}$.

The heat released was registered immediately after the addition of water in the mortar. The specimens were molded in expanded polystyrene (EPS) thermal cup of $120 \mathrm{~mL}$. The material was placed inside an EPS container filled with expansive polyurethane foam, aiming to achieve higher temperature insulation from the internal environment. In the central part of the specimens was inserted a thermocouple (K-type) to register the temperature through a data acquisition system (equipment: datalogger Testo 177-T4). The container with the mortars was kept in ambient conditions (average temperature registered during all the test time of $20.9{ }^{\circ} \mathrm{C}$ $\pm 2{ }^{\circ} \mathrm{C}$ ). Data were saved each $22 \mathrm{~s}$ during the total time of $2000 \mathrm{~min}$.

\subsubsection{Mechanical properties and statistical analysis}

To evaluate the importance of RHA dissolution (step 1 of one-part AAB synthesis, as presented in results), cubic mortars $(40 \mathrm{~mm} \times 40 \mathrm{~mm} \times 40 \mathrm{~mm})$ were molded (mix proportion in grams $=42$ alternative powder sodium silicate (APSS); 80 MK; 244 sand; and 66.3 water) and subjected to compressive strength test. Specimens were prepared with and without the previously RHA dissolution system proposed (heating and stirring) and the test was carried out in a Versa Tester machine (maximum load of $150 \mathrm{kN}$ ) at the ages of 3 , $7,28,90$, and 180 days.
Mechanical properties of mortars were evaluated by flexural and compressive strength tests at the ages of $3,7,28,90$, and 180 days (compressive strength) or 3 , 28, and 90 days (flexural strength). The specimens were tested in a Versa Tester machine (maximum load of $150 \mathrm{kN})$. Cubic samples $(40 \mathrm{~mm} \times 40 \mathrm{~mm} \times 40 \mathrm{~mm})$ were molded to the compressive strength test, which was obtained by the maximum load divided by the sample area $^{43}$. Prismatic samples $(40 \mathrm{~mm} \times 40 \mathrm{~mm} \times 160 \mathrm{~mm})$ were molded to flexural strength test, obtained by the three-point-bending test ${ }^{44}$.

Analysis of variance (ANOVA) (Microsoft Excel ${ }^{\circledR}$ software) and Least Square Difference (LSD) (Statgraphics Centurion ${ }^{\circledR}$ software) were made with a $95 \%$ confidence limit to compare the treatments.

\subsubsection{Air permeability and capillary water absorption}

Air permeability of the mortars was evaluated according to Thenoz method, such as presented by Geraldo et al. ${ }^{30}$.

Cylindrical specimens $(50 \mathrm{~mm}$ diameter and $100 \mathrm{~mm}$ height) were prepared and cured at room temperature for 25 days (average temperature of $25^{\circ} \mathrm{C} \pm 2{ }^{\circ} \mathrm{C}$ and relative humidity of $60 \% \pm 5 \%$ ). At this age, the specimens were cut into three parts and the central part slice $(50 \mathrm{~mm}$ height) was oven-dried $\left(60^{\circ} \mathrm{C} \pm 2{ }^{\circ} \mathrm{C}\right)$ for $48 \mathrm{~h}$ and after cooling they had their lateral surfaces sealed to guarantee the flow was uniaxial and perpendicular to the crosssectional area. The test was developed at 28 days in a varying charge apparatus. The average values of three specimens of each mortar composition were reported. Air permeability was calculated with Equation 1, which is based on Darcy's law.

$$
k=[\mu . s .1 /(\text { o.g.t.S })] \cdot \ln \left(h_{0} / h_{1}\right)
$$

Where: $\mathrm{k}=$ air permeability coefficient $\left(\mathrm{m}^{2}\right) ; \mu=$ air viscosity at the test temperature (Pa.s); $\rho=$ density of water $\left(\mathrm{kg} / \mathrm{m}^{3}\right)$; $\mathrm{g}=$ gravity acceleration $\left(\mathrm{m} / \mathrm{s}^{2}\right) ; \mathrm{S}=$ cross-sectional area of the sample $\left(\mathrm{m}^{2}\right) ; \mathrm{s}=$ cross-sectional area of capillary tube $\left(\mathrm{m}^{2}\right) ; \mathrm{h}_{0}=$ start water level $(\mathrm{m}) ; \mathrm{h}_{1}=$ final water level $(\mathrm{m})$; $1=$ sample height $(\mathrm{m})$; and $\mathrm{t}=$ testing time (s) (time to water pass from $h_{0}$ to $h_{1}$ ).

A capillary water absorption test was performed on cylindrical specimens ( $50 \mathrm{~mm}$ diameter and $100 \mathrm{~mm}$ height) at 28 days. The average values of three specimens for each mortar composition were reported and the test was based on NBR $9779^{45}$ with some modifications, as follows.

The specimens were oven-dried $\left(60{ }^{\circ} \mathrm{C} \pm 2{ }^{\circ} \mathrm{C}\right)$ for $48 \mathrm{~h}$. Thereafter, the samples were weighed and had their lateral surfaces sealed before testing to have the water flow perpendicular to the cross-sectional area. The specimens were partially immersed in water $(5 \mathrm{~mm} \pm 1 \mathrm{~mm})$ and the water uptake into the specimens was evaluated at $5 \mathrm{~min}, 10 \mathrm{~min}$, $15 \mathrm{~min}, 30 \mathrm{~min}, 1 \mathrm{~h}, 2 \mathrm{~h}, 4 \mathrm{~h}, 6 \mathrm{~h}, 8 \mathrm{~h}$, and 24 h. Capillary water absorption was calculated with Equation 2.

$$
C w a=\left(H_{m}-D_{m}\right) / S
$$

Where: Cwa $=$ capillary water absorption $\left(\mathrm{kg} / \mathrm{m}^{2}\right) ; \mathrm{H}_{\mathrm{m}}=$ humid mass $(\mathrm{kg})$; $\mathrm{D}_{\mathrm{m}}=$ oven-dried mass $(\mathrm{kg})$; and $\mathrm{S}=$ crosssectional area of the specimen $\left(\mathrm{m}^{2}\right)$. 


\subsubsection{Scanning electron microscopy (SEM) observations}

Scanning electron microscopy (SEM) by secondary electron images were obtained on fractured surfaces from compressive strength test specimens. The images were observed on LEO Electron Microscopy/Oxford 440i with $20 \mathrm{kV}$ and $100 \mathrm{pA}$. The equipment contained X-ray dispersive energy detector (EDS) and chemical analysis was performed. The samples were coated with gold before SEM observations.

\section{Results and Discussions}

\subsection{Synthesis of one-part $A A B$}

The method to one-part $\mathrm{AAB}$ obtaining was divided into steps as shown in Figure 4 and described, as follows.

\subsubsection{Alternative powder sodium silicate (APSS) production}

The APSS production comprises steps 1 to 3 (Figure 4).

Step 1- RHA silica dissolution: RHA was blended into a $\mathrm{NaOH}$ solution. The mix proportion employed was equal to (in mass) $1 \mathrm{NaOH}: 1.605$ water : 1.284 RHA. The mixture was put in a magnetic stirrer (equipment: Fisatom
$752 \mathrm{~A}$ ) with heating $\left(90^{\circ} \mathrm{C} \pm 5^{\circ} \mathrm{C}\right)$ for $30 \mathrm{~min}$, following the process described by Geraldo et al. ${ }^{30}$ to produce twopart AAB. Due to the high viscosity of the material, it was used another mechanical stirrer (equipment: Fisatom 713D, rotation range: 500-600 rpm) equipped with a stainless-steel stem to maintain the mixing.

The liquid material originated in this step had high viscosity and density $=1600 \mathrm{~kg} / \mathrm{m}^{3}, \mathrm{pH}=14$, total solid content $=65 \%$, and humidity content $=35 \%$.

The main objective of this step is to use RHA as a source of silica to synthesis an alternative sodium silicate (ASS) $)^{21,27}$, first in liquid phase (ASS) and in powder (APSS) in this work. Different results in the literature indicate the suitability of using RHA to obtain an ASS $^{32}$.

Step 2- Oven-drying: The material from step 1 was collected and spread in a rectangular aluminum tray (thickness $=\sim 5 \mathrm{~mm}$ ). This viscous liquid was oven-dried (temperature of $200^{\circ} \mathrm{C} \pm 10^{\circ} \mathrm{C}$ for $3 \mathrm{~h}$ ) in a stationary kiln with air circulation. Different preliminary trials were carried out with lower drying temperatures $\left(50^{\circ} \mathrm{C}, 100^{\circ}, 150^{\circ} \mathrm{C}\right)$; however, during this process, a film was formed over the material layer, which prevented water evaporation. Because of it, a temperature of $200^{\circ} \mathrm{C}$ was employed. To compare, Vinai and Soutsos ${ }^{46}$ made the oven-dry process to obtain a
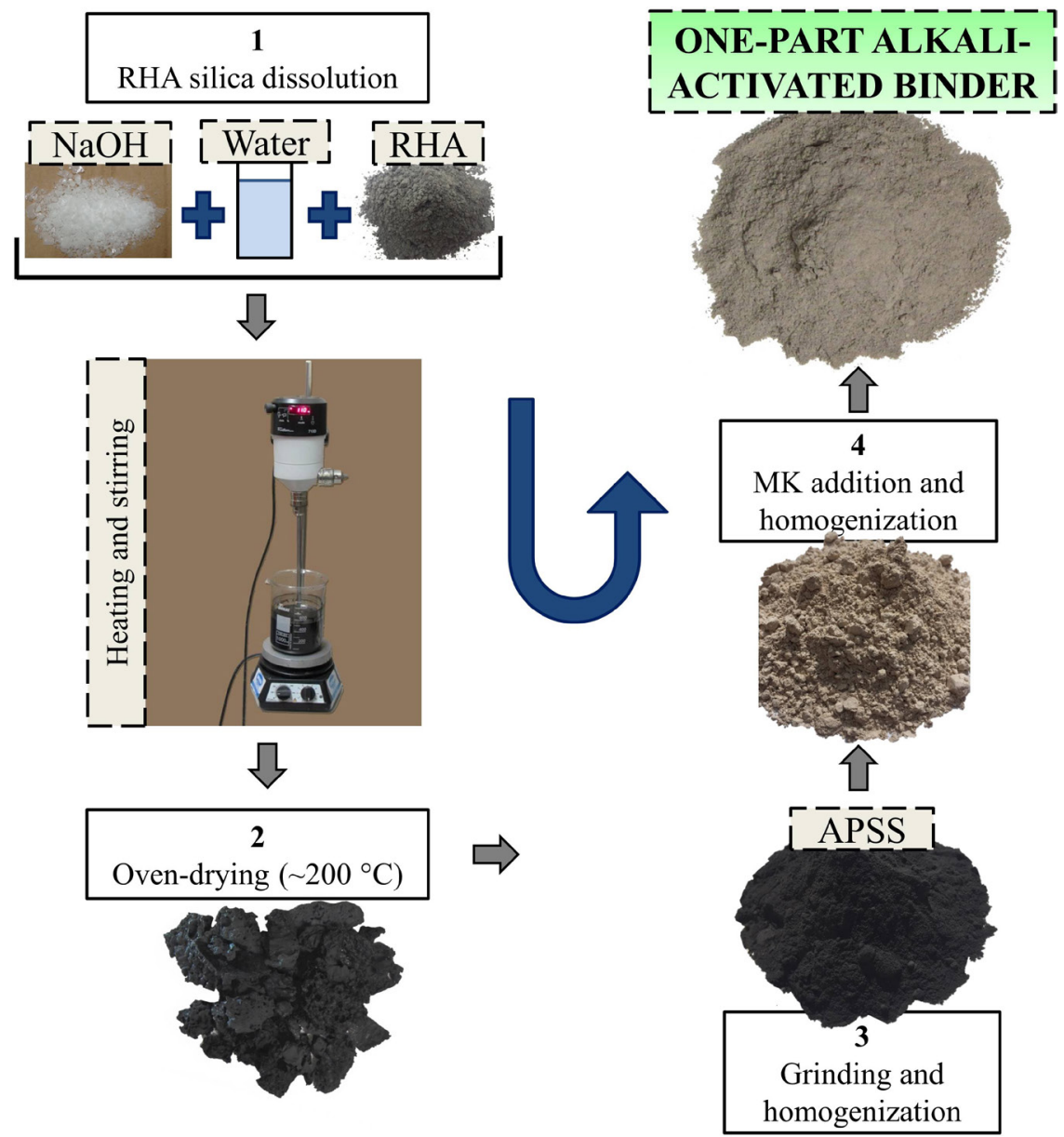

Figure 4. Steps to production of one-part AAB proposed. 
reactive powder using the temperature of $330{ }^{\circ} \mathrm{C}$ for $2 \mathrm{~h}$, revealing higher temperatures may decrease the total dry time.

Step 3- Grinding and homogenization: during this process, the dried material from step 2 was grounded in a porcelain ball mill until reaching a fineness to pass through a $0.075 \mathrm{~mm}$ sieve opening. The resultant material was manually homogenized using a plastic container, and it was designed as APSS.

Table 3 and Figure 5 show the chemical composition of APSS obtained by XRF and the XRD pattern of APSS, respectively.

XRF revealed that APSS is predominantly composed of silica, derived from RHA, and sodium, derived from $\mathrm{NaOH}$. $\mathrm{SiO}_{2}$ and $\mathrm{Na}_{2} \mathrm{O}$ represent more than $85 \%$ of the APSS total chemical composition. The APSS silica modulus $\mathrm{Ms} \mathrm{SiO}_{2} /$ $\mathrm{Na}_{2} \mathrm{O}$ molar ratio was equal to 1.69 , a value higher than the silica modulus of 1.25 stated by Gado et al. ${ }^{47}$ as an optimum condition to alkali-activation of waste clay bricks. APSS had a $\mathrm{pH}$ of 13.26 .

XRD shows a low-crystalline material, indicating a reactive powder. Step 1 (dissolution of $\mathrm{NaOH}+\mathrm{RHA}$ ) was efficient in breaking the cristobalite peak, as indicated by Mejía et al. ${ }^{28}$. This crystal has a high dissolution susceptibility to being removed by an alkaline source. The crystalline phases in APSS revealed by XRD peaks were identified as $\mathrm{NaOH}\left(\mathrm{H}_{2} \mathrm{O}\right)$ (COD ID: 1532133$), \mathrm{Na}_{2}\left(\mathrm{Si}_{2} \mathrm{O}_{5}\right)$ (COD ID: 1533028), and $\mathrm{Na}_{2} \mathrm{SiO}_{3}$ (COD ID: 2310858). Considering the chemical stoichiometry and the products identified by XRD, the products were formed following the overall chemical reactions in solution (Reactions 1 to 4 ).

$$
\begin{gathered}
2 \mathrm{NaOH} \rightarrow \mathrm{Na}_{2} \mathrm{O}+\mathrm{H}_{2} \mathrm{O} \\
\mathrm{Na}_{2} \mathrm{O}+\mathrm{H}_{2} \mathrm{O}+\mathrm{SiO}_{2} \rightarrow \mathrm{Na}_{2} \mathrm{SiO}_{3}+\mathrm{H}_{2} \mathrm{O}
\end{gathered}
$$

$$
\begin{gathered}
\mathrm{Na}_{2} \mathrm{SiO}_{3}+\mathrm{SiO}_{2} \rightarrow \mathrm{Na}_{2} \mathrm{Si}_{2} \mathrm{O}_{5} \\
\mathrm{Na}_{2} \mathrm{O}+2 \mathrm{H}_{2} \mathrm{O} \rightarrow 2 \mathrm{NaOH} \cdot \mathrm{H}_{2} \mathrm{O}
\end{gathered}
$$

Reaction 1 represents $\mathrm{NaOH}$ in flakes dissolved in water $^{48}$. $\mathrm{NaOH}$ solution dissolves the RHA silica to form sodium silicate, as shown in Reaction $2^{21,46}$. The $\mathrm{Na}_{2} \mathrm{SiO}_{3}$ and $\mathrm{Na}_{2}\left(\mathrm{Si}_{2} \mathrm{O}_{5}\right)$ phases are sodium silicate from RHA and $\mathrm{NaOH}$. It indicates that the procedure for RHA silica dissolution was efficient.

TG curves (Figure 6) indicated a continuous mass loss, more pronounced at $200{ }^{\circ} \mathrm{C}-350{ }^{\circ} \mathrm{C}$, with a DTG peak at $282{ }^{\circ} \mathrm{C}$, due to the water loss. There was a low endothermic DTA peak at $800{ }^{\circ} \mathrm{C}$, which can be attributed to calcium carbonate decomposition ${ }^{49}$. Another exothermic DTA peak at $858^{\circ} \mathrm{C}$ can be related to the $\beta$-tridymite formation derived from the silica heating at the range of $870{ }^{\circ} \mathrm{C}^{50}$.

\subsubsection{One-part $A A B$}

The production of one-part AAB, after the APSS production, comprises steps 4 and 5 .

Step 4- $M K$ addition and homogenization: MK was added to APSS in determined proportions, and the powders were manually mixed in a sealed container until complete homogenization.

Step 5- One-part $A A B$ : after the process described, the one-part $\mathrm{AAB}$ was obtained, and it was ready to be used only with the water addition. Considering the three different $\mathrm{SiO}_{2} /$ $\mathrm{Al}_{2} \mathrm{O}_{3}$ molar ratios tested in this study and Table 4 shows some characteristics of the obtained binders.

The results indicated that the physical properties of the

\begin{tabular}{|c|c|c|c|c|c|c|c|c|c|}
\hline \multirow{2}{*}{ Sample } & \multicolumn{9}{|c|}{ Composition (wt.\%) } \\
\hline & $\mathrm{SiO}_{2}$ & $\mathrm{Na}_{2} \mathrm{O}$ & $\mathrm{Al}_{2} \mathrm{O}_{3}$ & $\mathrm{~K}_{2} \mathrm{O}$ & $\mathrm{CaO}$ & $\mathrm{MgO}$ & $\mathrm{Fe}_{2} \mathrm{O}_{3}$ & Others & LOI \\
\hline APSS & 53.80 & 32.80 & 1.72 & 1.01 & 0.36 & 0.16 & 0.05 & 0.52 & 9.58 \\
\hline
\end{tabular}
binders B_3.1 and C_3.3 were similar. A_2.7 presented a slightly higher $\mathrm{pH}$ due to the incorporation of extra $\mathrm{NaOH}$,

Table 3. Chemical composition of alternative sodium silicate (APSS) in powder.

${ }^{1}$ Loss on ignition
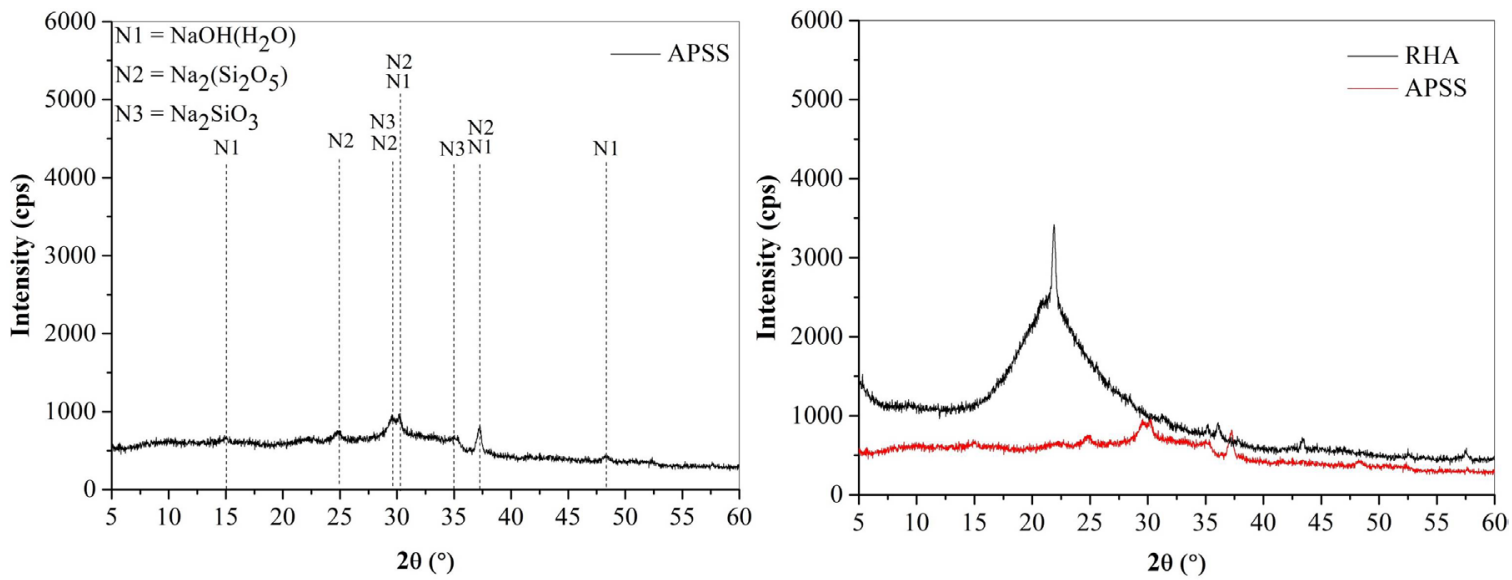

Figure 5. XRD results of APSS (a) and XRD of RHA and APSS (b). 
Table 4. Characteristics of the one-part $\mathrm{AAB}$ produced considering the theoretical $\mathrm{SiO}_{2} / \mathrm{Al}_{2} \mathrm{O}_{3}$ molar ratio.

\begin{tabular}{ccccc}
\hline Sample & Molar ratio $(\mathrm{m} / \mathrm{m})$ & $\mathrm{pH}$ & Bulk density $\left(\mathrm{kg} / \mathrm{m}^{3}\right)$ & Specific mass $\left(\mathrm{kg} / \mathrm{m}^{3}\right)$ \\
\hline A_2.7 & 2.7 & 13.13 & 552 & 2525 \\
\hline B_3.1 & 3.1 & 12.81 & 573 & 2513 \\
\hline C_3.3 & 3.3 & 12.81 & 586 & 2513 \\
\hline
\end{tabular}

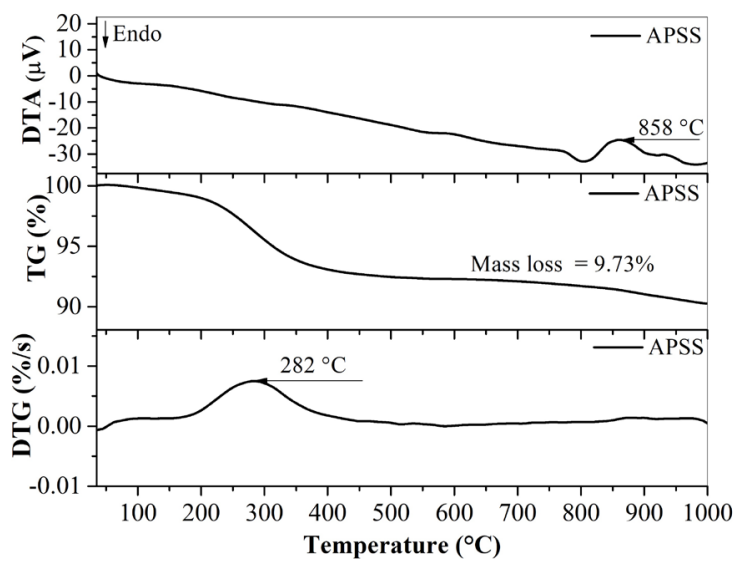

Figure 6. TG/DTG/DTA curves of APSS.

used to correct the molar $\mathrm{Na}_{2} \mathrm{O} / \mathrm{Al}_{2} \mathrm{O}_{3}$ ratio. The values of $\mathrm{pH}$ are very close to that presented by $\mathrm{PC}$, which is around $13^{51}$.

\subsection{Importance of RHA silica dissolution (step 1)}

Figure 7 shows the effect of step 1 (RHA silica dissolution with heating and stirring) on compressive strength of mortars, comparing results with mortars made with an equivalent system, but just adding RHA into $\mathrm{NaOH}$ solution and going on with other processes.

The results indicated that the RHA dissolution by heating and mixing is important in strength development. The mortar made with one-part AAB produced with RHA dissolution (step 1) achieved a compressive strength 2.8 times higher than the mortar made just by mixing RHA into $\mathrm{NaOH}$ solution and following the next steps. The difference is because the steps (heating and mixing) to prepare APSS supplied a higher amount of amorphous silicate, which contributed to the mechanical strength development, as explained by Autef et al. ${ }^{52}$.

RHA dissolution also provided a higher strength increases over time. The chemical mechanism of APSS to dissolve the aluminosilicate precursor (metakaolin) is expected to be similar to the activator containing only $\mathrm{NaOH}$, the difference is that APSS accelerates the reaction by supplying soluble silicate from the activator ${ }^{21}$.

\subsection{Mortars made with one-part AAB containing different $\mathrm{SiO}_{2} / \mathrm{Al}_{2} \mathrm{O}_{3}$ molar ratios}

The flow table test indicated A_2.7, B_3.1, and C_3.3 with flows of $130 \mathrm{~mm}, 129 \mathrm{~mm}$, and $124 \mathrm{~mm}$, respectively. The results indicated that all mortars had low workability. The workability of mortars was similar, with a low spread diameter. This can be explained by the physical characteristics of the powder binder used (e.g. water absorption, grain size)

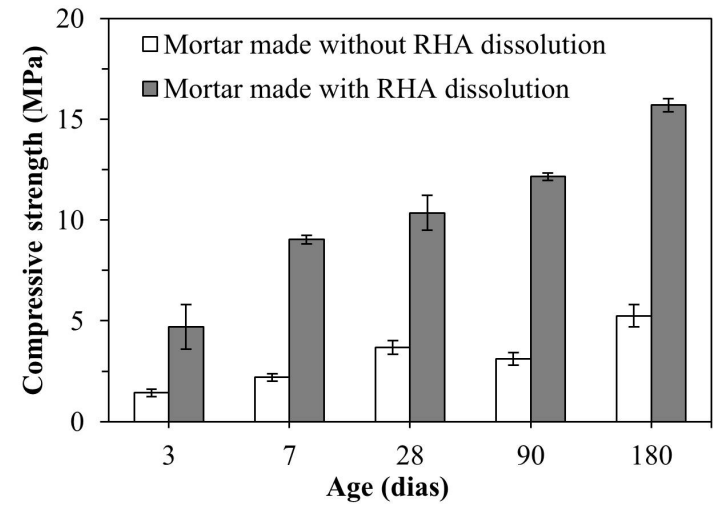

Figure 7. Influence of RHA dissolution step in the compressive strength of mortars made with one-part AAB.

and the water content that was not sufficient to reach good workability.

Figure 8 shows the results of heat evolution curves of mortars immediately after water addition.

The temperature registered with time indicated an exothermic chemical reaction (heat release). The heat curves of B_3.1 and C_3.3 presented a similar pattern and reached the maximum temperatures registered after about $1 \mathrm{~h}$. The use of additional $\mathrm{NaOH}$ in A_2.7 did not result in an acceleration of chemical reactions, differently, the curves indicated that in this sample there was a lower heat releasing and the reaction occurred slower, where the maximum temperature delayed 4 times more than the other AAB mix designs.

Each curve presented only one maximum temperature peak, a result similar to that obtained by Longhi et al.$^{53}$ and Geraldo et al. ${ }^{30}$ with two-part AAB. The peak presented in the curves is related to the chemical reactions of dissolution and polycondensation from alkaline activation, which happen almost at the same time $e^{53,54}$.

Figure 9 shows the results of compressive strength (Figure 9a) and flexural strength (Figure 9b) of the mortars, respectively. ANOVA indicated there was a significant difference among the data set considering flexural or compressive strength results ( $p$-value $\leq 0.05$ and Fcrit $<F$ ). Table 5 shows the analysis obtained by the Least Square Difference (LDS) to compare the treatments.

The results indicated that compressive strengths increased with time. The increase was more evidenced in B_3.1 and C_3.3, while A_2.7 did not obtain a significant increase after 28 days. The compressive strength from 3 to 90 days of A_2.7, B_3.1, and C_3.3 increased in the order of 2.4, 2.6, and 2.2 times, respectively. The strength development may be related to the slow RHA silica dissolution when the binder is mixed with water. As showed by Luukkonen et al. ${ }^{55}$, 


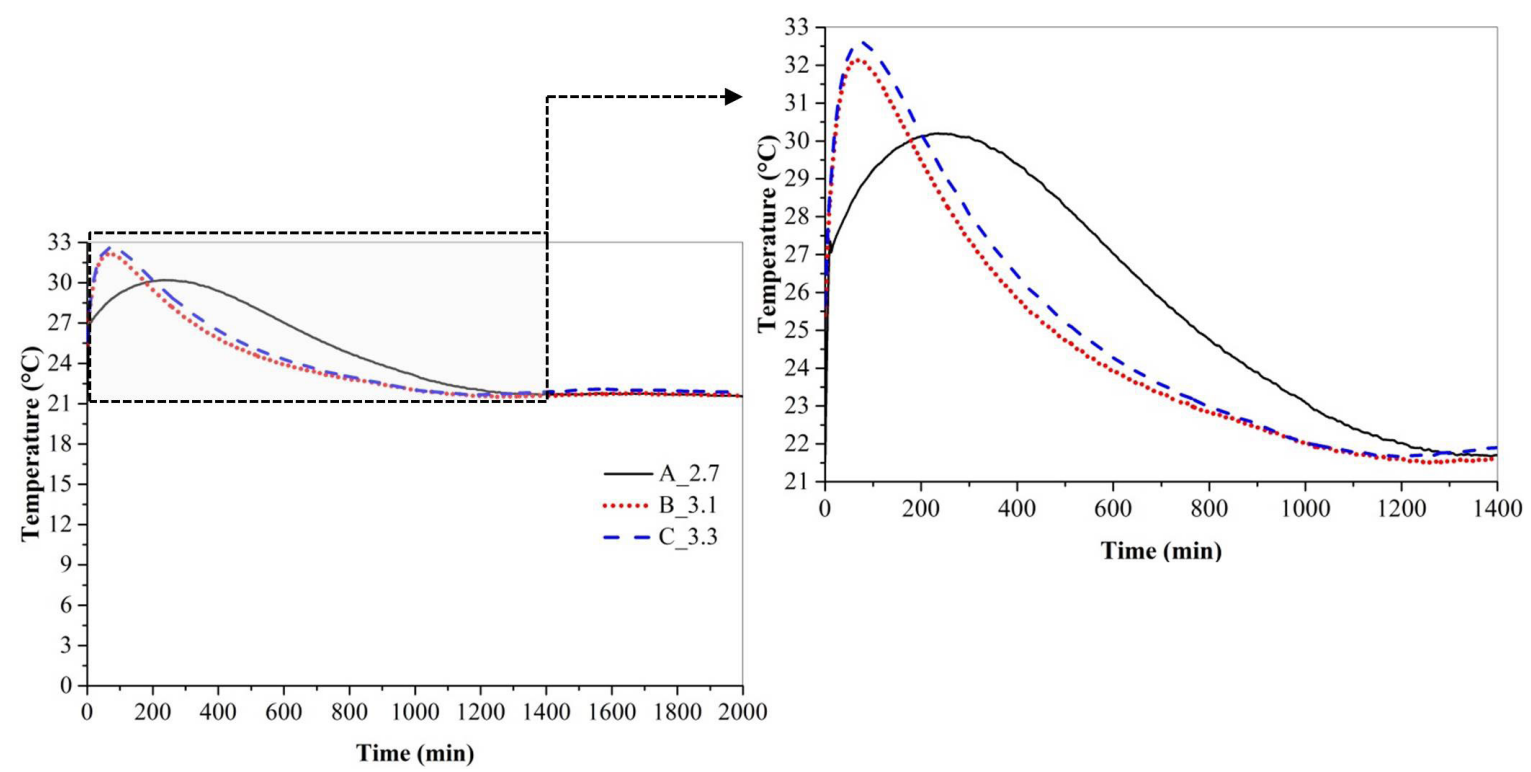

Figure 8. Heat evolution curves of the mortars made with the one-part AAB immediately after water addition (a) with magnification from $21{ }^{\circ} \mathrm{C}$ to $33{ }^{\circ} \mathrm{C}$ (b) (average ambient temperature during the test $=20.9{ }^{\circ} \mathrm{C} \pm 2{ }^{\circ} \mathrm{C}$ ).
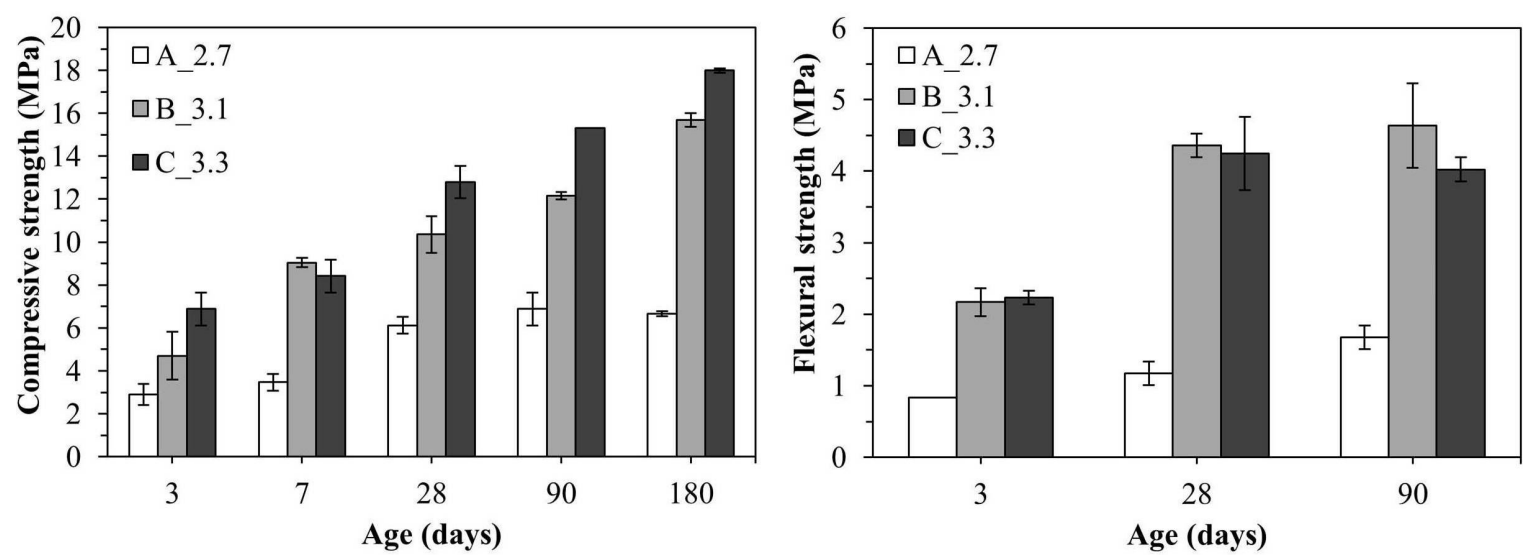

Figure 9. Compressive (a) and flexural (b) strengths of mortars made with the one-part AAB.

the slow silica availability results in continuous gain strength by increasing the degree of reaction.

The mechanical strength of the mortars also increased with the higher $\mathrm{SiO}_{2} / \mathrm{Al}_{2} \mathrm{O}_{3}$ molar ratios used, indicating the importance of the initial composition. Statistics indicate a significant difference in compressive strength according to $\mathrm{SiO}_{2} / \mathrm{Al}_{2} \mathrm{O}_{3}$ molar ratio in most of the curing times. Considering flexural strength, the specimens B_3.1 and C_3.3 did not present significant differences.

In the literature, other authors reported strength increasing with higher $\mathrm{SiO}_{2} / \mathrm{Al}_{2} \mathrm{O}_{3}$ molar ratio to $\mathrm{AAB}$ production ${ }^{56,57}$. The strength increase is associated with higher $\mathrm{Si}-\mathrm{O}-\mathrm{Si}$ bonds and lower Si-O-Al bonds formation, derived from the more significant degree of $\mathrm{SiO}_{2}$ available. The threedimensional networks Si-O-Si bonds have more strength than $\mathrm{Si}-\mathrm{O}-\mathrm{Al}$ bonds, resulting in a material with improved mechanical strength with denser and more homogeneous microstructures ${ }^{56-58}$.
The maximum compressive strength achieved was $\sim 18 \mathrm{MPa}$ at 180 days, which was lower than other literature values about one-part AAB. Mortars produced with AAB achieved lower compressive strength than mortars in a two-part method produced by Geraldo et al. ${ }^{30}$ and Teixeira et al. ${ }^{31}$ using similar materials. The authors reported compressive strength in the range of $29 \mathrm{MPa}-40 \mathrm{MPa}$ at 28 days. Nevertheless, the data indicate that the one-part $\mathrm{AAB}$ proposed generated material with binding properties and compressive strength higher than required for non-structural applications, such as mortars for components and rendering ${ }^{59}$. According to Brazilian standards, the minimum compressive strengths for some applications are: ceramic bricks $=$ higher than 1.5 $\mathrm{MPa}$, soil cement brick = higher than $2.0 \mathrm{MPa}$, concrete blocks for sealing = higher than $2.5 \mathrm{MPa}$, ceramic blocks for structural masonry = higher than $3 \mathrm{MPa}$, and hollow concrete blocks of $\mathrm{C}$ category $=$ higher than $4 \mathrm{MPa}$. 
Table 5. LSD test with a 95\% confidence limit.

\begin{tabular}{cccccc}
\hline \multirow{2}{*}{ Sample } & \multicolumn{7}{c}{ Age (days) } \\
\cline { 2 - 6 } & \multicolumn{7}{c}{7} & 28 & 90 & 180 \\
\hline A_2.7 & $2.89 \mathrm{aA}$ & $3.47 \mathrm{aA}$ & $6.11 \mathrm{bA}$ & $6.89 \mathrm{bA}$ & $6.66 \mathrm{bA}$ \\
\hline B_3.1 & $4.70 \mathrm{aB}$ & $9.03 \mathrm{bB}$ & $10.35 \mathrm{cB}$ & $12.14 \mathrm{~dB}$ & $15.69 \mathrm{eB}$ \\
\hline C_3.3 & $6.89 \mathrm{aC}$ & $8.42 \mathrm{bB}$ & $12.79 \mathrm{cC}$ & $15.31 \mathrm{dC}$ & $17.99 \mathrm{eC}$ \\
\hline A_2.7 & & Flexural strength $(\mathrm{MPa})$ & \\
\hline B_3.1 & $0.83 \mathrm{aA}$ & - & $1.17 \mathrm{bA}$ & $1.67 \mathrm{cA}$ & - \\
\hline C_3.3 & $2.17 \mathrm{aB}$ & - & $4.35 \mathrm{bB}$ & $4.63 \mathrm{bB}$ & - \\
\hline
\end{tabular}

Row data: the same lower-case letters indicate similar statistics results (strength evolution with curing time). Column data: the same upper-case letters indicate similar statistics results (strength values among the groups).
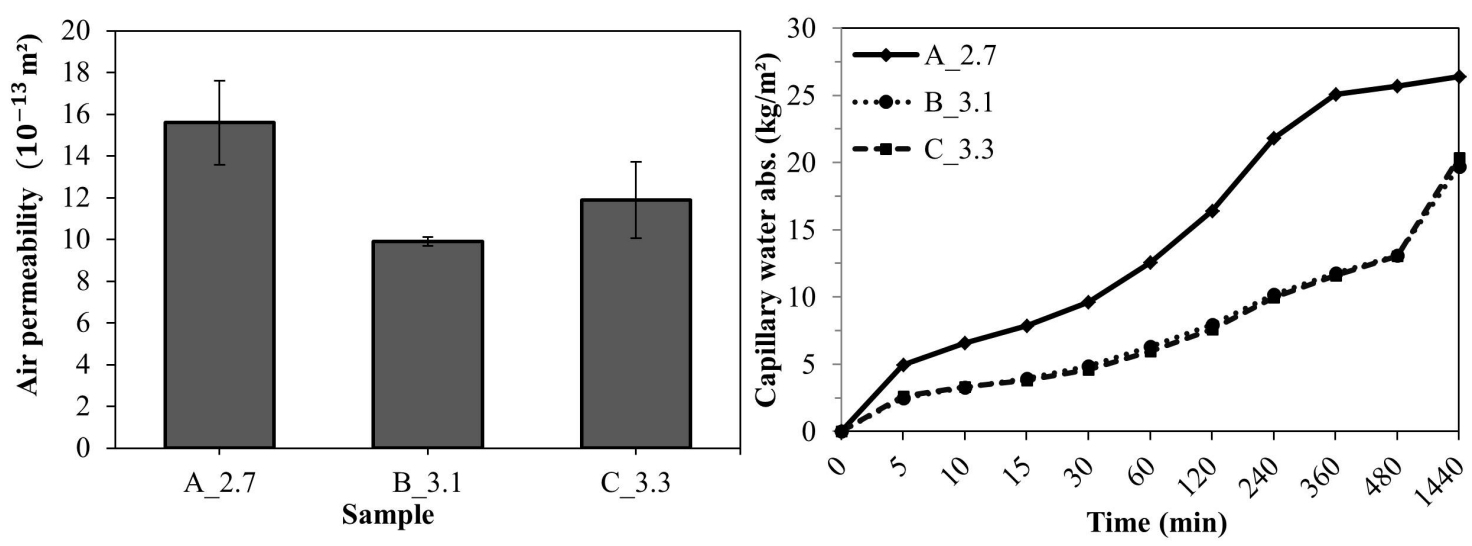

Figure 10. Air permeability (a) and capillary water absorption (b) of the AAB mortars.

The use of more reactive precursors and a thinner APSS could improve the AAB reactivity and, as a result, the mechanical strength.

Figure 10 exhibits the results of air permeability (Figure 10a) and water absorption (Figure 10b) of the hardened mortars.

The results indicated that A_2.7 was a more permeable mortar. The additional water used to dissolve the extra $\mathrm{NaOH}$ and to adjust the molar ratio $\mathrm{H}_{2} \mathrm{O} / \mathrm{Na}_{2} \mathrm{O}$ contributes to the porosity increasing in hardened mortar, as reported by Cheng et al. ${ }^{60}$.

Air permeability results obtained in a two-part $\mathrm{AAB}$ mortar made with APSS from RHA were $1 \times 10^{-13} \mathrm{~m}^{230}$, while the results obtained in this research with one-part $\mathrm{AAB}$ made with APSS were 10 times higher. The high permeability can be related to entrapped air in the mortars, which is derived mainly by the difficulty of mixing and molding the mortars in the fresh state due to the low workability.

The capillary water absorption results indicated that within the first $480 \mathrm{~min}$ the differences between the capillarity of A_2.7 and other specimens increased with time. After $24 \mathrm{~h}$, A_2.7 had capillary water absorption 30\% higher than the other mortars. The specimens B_3.1 and C_3.3 presented similar behavior during all tests, which indicates that they have a similar internal capillary pores network ${ }^{11}$.

The results suggest that in sample A_2.7 there was a broader number and connection of pores, resulting in a higher capillary suction ${ }^{61}$. The data are in accordance with the air permeability tests that indicated A_2.7 was a more permeable material. B_3.1 and C_3.3 provided lower internal water transport by capillary forces, indicating they are materials of higher durability than A_2. $7^{62}$.

Figure 11 shows the morphology of the mortars obtained by SEM. The numbers 1, 2, 3, and 4 presented in the images indicated the EDS point of detection. Table 6 presents the results of the chemical composition obtained by EDS (average value obtained at least two reading points in diverse regions of specimens).

Figure 11 revealed that the specimen microstructures were homogeneous, dense, and presented micro-cracks and voids usually with spherical shapes distributed by the matrix (porosity).

The observed samples were fractured from the specimens of compressive strength test. This can cause some microcracks observed in the microstructure. In the literature, other studies reported microcracks in one-part $\mathrm{AAB}$ which may also be due to some expansive reactions in the hardened material ${ }^{10}$. Spherical voids reveal the presence of trapped air bubbles that contribute to total porosity ${ }^{36}$.

Mortar matrix A_2.7 microstructure revealed the presence of elongated needle-shaped crystals. This is due to the additional $\mathrm{NaOH}$ and water in the mixture, necessary to keep a constant $\mathrm{Na}_{2} \mathrm{O} / \mathrm{Al}_{2} \mathrm{O}_{3}$ and $\mathrm{H}_{2} \mathrm{O} / \mathrm{Na}_{2} \mathrm{O}$ molar ratios, resulting in unreacted and free alkalis. The unreacted and free alkalis react with $\mathrm{CO}_{2}$ to form efflorescence ${ }^{63}$. Temuujin et al. ${ }^{64}$ stated that efflorescence is mainly composed of $\mathrm{Na}$ and $\mathrm{O}$, with a chemical composition ranging in according to the precursor employed. 

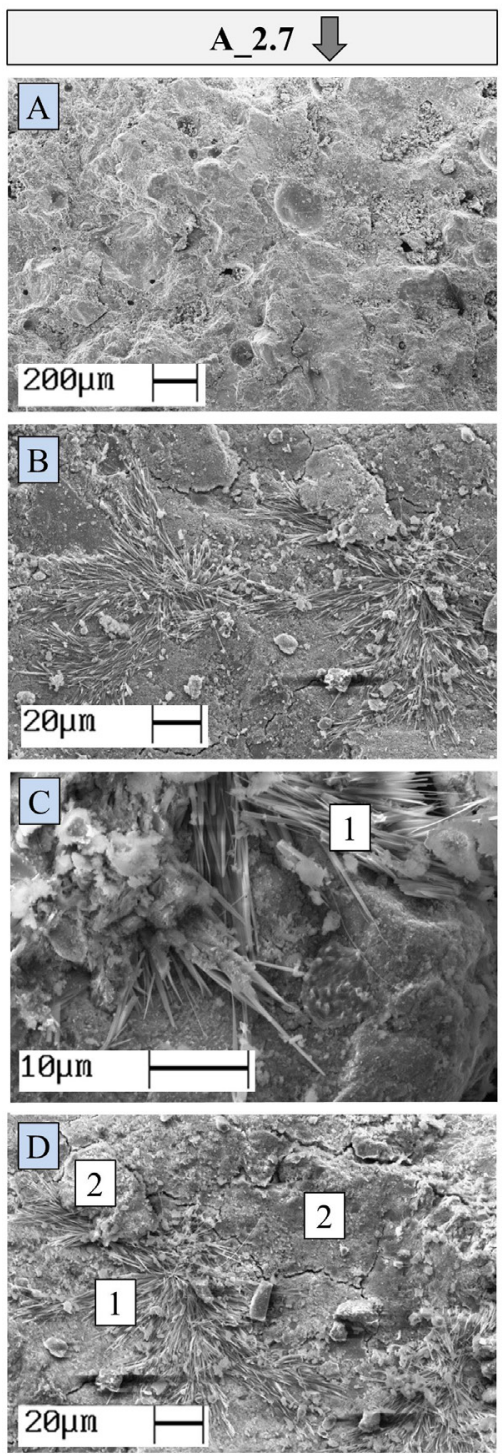
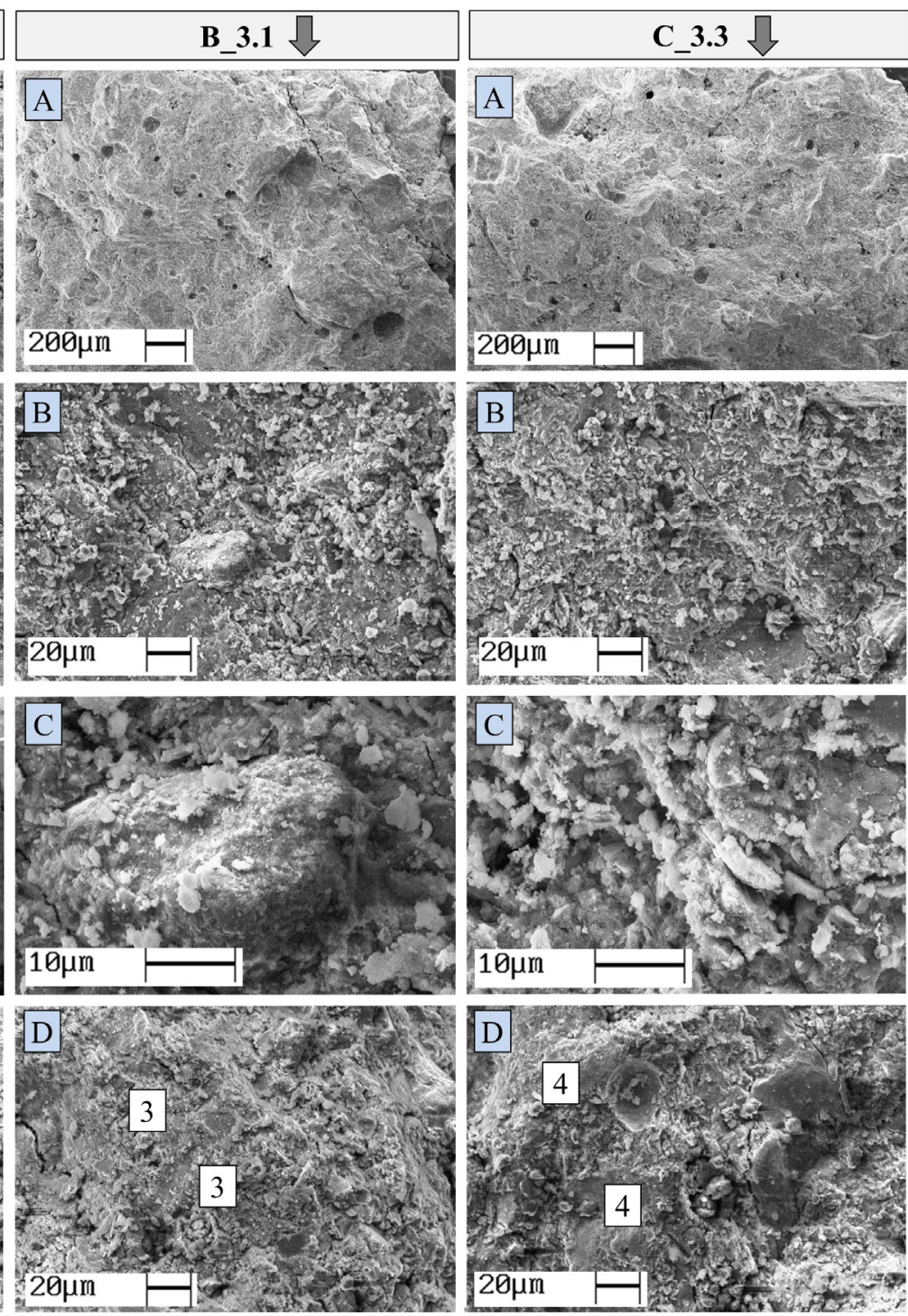

Figure 11. Microstructure of mortars obtained by SEM.

Table 6. Elemental composition of mortars (obtained by EDS).

\begin{tabular}{|c|c|c|c|c|c|c|c|c|c|c|}
\hline \multirow{2}{*}{ Sample } & \multicolumn{7}{|c|}{ Element $(\%)$} & \multicolumn{3}{|c|}{ Molar ratio $(\mathrm{m} / \mathrm{m})$} \\
\hline & $\mathrm{O}$ & $\mathrm{Si}$ & $\mathrm{Al}$ & $\mathrm{Na}$ & $\mathrm{K}$ & $\mathrm{Fe}$ & Others & $\mathrm{Na} / \mathrm{Al}$ & $\mathrm{Na} / \mathrm{Si}$ & $\mathrm{Si} / \mathrm{Al}$ \\
\hline $1 \mathrm{~A} \_2.7$ & 53.63 & 12.25 & 6.68 & 20.99 & 0.91 & 0.75 & 4.79 & 3.69 & 2.09 & 1.76 \\
\hline $2 \mathrm{~A} \_2.7$ & 51.34 & 23.05 & 14.59 & 6.11 & 1.24 & 1.01 & 2.66 & 0.49 & 0.32 & 1.51 \\
\hline 3 B_3.1 & 50.43 & 27.50 & 13.66 & 5.66 & 0.95 & 0.72 & 1.08 & 0.48 & 0.25 & 1.93 \\
\hline 4 C_3.3 & 51.32 & 26.00 & 12.28 & 6.47 & 1.87 & 1.13 & 0.93 & 0.61 & 0.30 & 2.03 \\
\hline
\end{tabular}

The high $\mathrm{Na} / \mathrm{Si}$ and $\mathrm{Na} / \mathrm{Al}$ ratios obtained from EDS point 1 (Figure 11 - A_2.7, images $\mathrm{C}$ and D) revealed the concentration of sodium in the needle-like crystals, while the concentrations were considerably lower in the A_2.7 matrix indicated by EDS point 2 (Figure $11-$ A_2.7, image D). During the crystal formations, internal pressure can be generated ranging according to pore diameter and, in some cases, it causes cracking ${ }^{65}$.

Mortar matrix B_3.1 presented a continuous and dense microstructure with pores and cracks. Figure 11 - B_3.1, images B and C showed small zeolite crystals formed on the matrix surface as secondary products in the reaction process (on the N-A-S-H gel) which is the precursor of zeolites formation ${ }^{66,67}$. Sample B_3.1 had a Si/Al molar ratio lower than 0.3. Ma et al ${ }^{68}$ results showed that in these cases the N-A-S-H gels may have been few geopolimerized which results in the formation of the zeolitic phase.

Mortar matrix C_3.3 presented a continuous and dense microstructure. Figure $11-$ C 3 3.3, image C, present crystals similar to the zeolitic phase, but EDS measurements were 
not made on these surfaces, and it makes difficult to confirm this phase formation. Mortar C_3.3 presented the $\mathrm{Na} / \mathrm{Si}$ and $\mathrm{Si} / \mathrm{Al}$ molar ratios very close to the results available in the literature.

The elemental compositions obtained by EDS showed the molar ratios: $\mathrm{Na} / \mathrm{Al}$ varying from 0.48 to $0.61 ; \mathrm{Na} / \mathrm{Si}$ varying from 0.25 to 0.32 ; and $\mathrm{Si} / \mathrm{Al}$ varying from 1.51 to 2.03. The EDS results in point 1 were not considered because it was made on the alkaline crystal. Guo et al. ${ }^{69}$ reported $\mathrm{Na} / \mathrm{Si}$ molar ratios between 0.28 and 0.51 , and stated that the best ratio was close to 0.5 where occurred the greatest formation of N-A-S-H gel. Duxon et al. ${ }^{58}$ studied the $\mathrm{Si}$ / Al molar ratio between 1.15 and 2.15, and reported that the higher mechanical properties were achieved with $\mathrm{Si} / \mathrm{Al}$ molar ratio of 1.90. The mechanical properties of B_3.1 and C_3.3 mortars had better results.

The results of one-part AAB obtained in this work confirm that the process to obtain this one-part binder is a viable economic alternative in diverse applications, such as fire-proof building materials, protective coatings, renderings, and building components.

\section{Conclusions}

A method to produce one-part alkali-activated binder (AAB) was carried out by the following steps: 1- production of alternative powder sodium silicate solution; 2- oven-drying the solution; 3 - grinding to obtain a sodium silicate as a thin powder (APSS); 4- addition of metakaolin to the APSS; and 5 - the binder is ready (one-part AAB).

The $\mathrm{SiO}_{2} / \mathrm{Al}_{2} \mathrm{O}_{3}$ molar ratio used in mortar production affected the final properties. The increase in $\mathrm{SiO}_{2}$ content generated mortar with higher strength and lower porosity.

The highest compressive strength $(\sim 18 \mathrm{MPa})$ was achieved at 180 days by mortar produced with a theoretical $\mathrm{SiO}_{2} / \mathrm{Al}_{2} \mathrm{O}_{3}$ molar ratio of 3.3. Despite the relatively low mechanical results, the mortars achieved enough compressive strength for different applications in civil construction (renderings and components).

Data indicated the effectiveness of the proposed method of production one-part AAB. The use of a solid silicate soluble source from rice husk ash (agricultural waste) dissolution makes the $\mathrm{AAB}$ production cleaner when compared with other commercial activators, resulting in environmental benefits.

\section{Acknowledgments}

This work was supported by the Coordination for the Improvement of Higher Education Personnel - Brazil (CAPES, Finance code: 001), PROCAD/CAPES, and National Council for Scientific and Technological Development - Brazil (CNPq).

\section{References}

1. Nematollahi B, Sanjayan J, Shaikh FUA. Synthesis of heat and ambient cured one-part geopolymer mixes with different grades of sodium silicate. Ceram Int. 2015;41(4):5696-704. http://dx.doi.org/10.1016/j.ceramint.2014.12.154.

2. Bernal SA, Provis JL. Durability of alkali-activated materials: progress and perspectives. J Am Ceram Soc. 2014;97(4):9971008. http://dx.doi.org/10.1111/jace.12831.
3. McNulty E. Geopolymers: an environmental alternative to carbon dioxide producing ordinary Portland cement [Internet]. 2009 [cited 2021 Aug 28]. Available from: http://citeseerx.ist.psu.edu/ viewdoc/download?doi=10.1.1.474.1240\&rep=rep1\&type=pdf

4. Provis JL. Geopolymers and other alkali activated materials: why, how, and what? Mater Struct. 2014;47(1-2):11-25. http:// dx.doi.org/10.1617/s11527-013-0211-5.

5. Carreño-Gallardo C, Tejeda-Ochoa A, Perez-Ordonez OI, Ledezma-Sillas JE, Lardizabal-Gutierrez D, Prieto-Gomez $\mathrm{C}$, et al. In the $\mathrm{CO}_{2}$ emission remediation by means of alternative geopolymers as substitutes for cements. J Environ Chem Eng. 2018;6(4):4878-84. http://dx.doi.org/10.1016/j.jece.2018.07.033.

6. Aiken TA, Kwasny J, Sha W, Soutsos MN. Effect of slag content and activator dosage on the resistance of fly ash geopolymer binders to sulfuric acid attack. Cement Concr Res. 2018;111:2340. http://dx.doi.org/10.1016/j.cemconres.2018.06.011.

7. Provis JL. Alkali-activated materials. Cement Concr Res. 2018;114:40-8. http://dx.doi.org/10.1016/j.cemconres.2017.02.009.

8. Luukkonen T, Abdollahnejad Z, Yliniemi J, Kinnunen P, Illikainen M. One-part alkali-activated materials: a review. Cement Concr Res. 2018;103:21-34. http://dx.doi.org/10.1016/j. cemconres.2017.10.001.

9. Tigue AAS, Malenab RAJ, Dungca JR, Yu DEC, Promentilla MAB. Chemical stability and leaching behavior of one-part geopolymer from soil and coal fly ash mixtures. Minerals. 2018;8(9):411. http://dx.doi.org/10.3390/min8090411.

10. Ma C, Zhao B, Guo S, Long G, Xie Y. Properties and characterization of green one-part geopolymer activated by composite activators. J Clean Prod. 2019;220:188-99. http:// dx.doi.org/10.1016/j.jclepro.2019.02.159.

11. Abdollahnejad Z, Hlavacek P, Miraldo S, Pacheco-Torgal F, Aguiar JLB. Compressive strength, microstructure and hydration products of hybrid alkaline cements. Mater Res. 2014;17(4):82937. http://dx.doi.org/10.1590/S1516-14392014005000091.

12. Yu J, Chen Y, Chen G, Wang L. Experimental study of the feasibility of using anhydrous sodium metasilicate as a geopolymer activator for soil stabilization. Eng Geol. 2020;264:105316. http://dx.doi.org/10.1016/j.enggeo.2019.105316.

13. Hajimohammadi A, Ngo T, Mendis P, Kashani A, van Deventer JSJ. Alkali activated slag foams: the effect of the alkali reaction on foam characteristics. J Clean Prod. 2017;147:330-9. http:// dx.doi.org/10.1016/j.jclepro.2017.01.134.

14. Dong M, Elchalakani M, Karrech A. Development of high strength one-part geopolymer mortar using sodium metasilicate. Constr Build Mater. 2020;236:117611. http://dx.doi.org/10.1016/j. conbuildmat.2019.117611.

15. Ma C, Zhao B, Wang L, Long G, Xie Y. Clean and low-alkalinity one-part geopolymeric cement: effects of sodium sulfate on microstructure and properties. J Clean Prod. 2020;252:119279. http://dx.doi.org/10.1016/j.jclepro.2019.119279.

16. Abdulkareem M, Havukainen J, Horttanainen M. Environmental assessment of alkali-activated mortars using different activators. In: 17th International Waste Management and Landfill Symposium [Internet]; 2019; Cagliari, Italy. Proceedings. Padova: EWA; 2019 [cited 2021 Aug 28]. Available from: http://urn.fi/ URN:NBN:fi-fe2019120345430

17. Abdel-Gawwad HA, Mohammed MS, Ads EN. A novel ecosustainable approach for the cleaner production of ready-mix alkali activated cement using industrial solid wastes and organicbased activator powder. J Clean Prod. 2020;256:120705. http:/ dx.doi.org/10.1016/j.jclepro.2020.120705.

18. Samarakoon MH, Ranjith PG, Duan WH, Silva VRS. Properties of one-part fly ash/slag-based binders activated by thermallytreated waste glass/ $\mathrm{NaOH}$ blends: a comparative study. Cement Concr Compos. 2020;112:103679. http://dx.doi.org/10.1016/j. cemconcomp.2020.103679.

19. Passuello A, Rodríguez ED, Hirt E, Longhi M, Bernal SA, Provis JL, et al. Evaluation of the potential improvement 
in the environmental footprint of geopolymers using wastederived activators. J Clean Prod. 2017;166:680-9. http://dx.doi. org/10.1016/j.jclepro.2017.08.007.

20. Abdulkareem M, Havukainen J, Nuortila-Jokinen J, Horttanainen M. Environmental and economic perspective of waste-derived activators on alkali-activated mortars. J Clean Prod. 2021;280:124651. http://dx.doi.org/10.1016/j.jclepro.2020.124651.

21. Adesanya E, Perumal P, Luukkonen T, Yliniemi J, Ohenoja K, Kinnunen P, et al. Opportunities to improve sustainability of alkali-activated materials: a review of side-stream based activators. J Clean Prod. 2021;286:125558. http://dx.doi. org/10.1016/j.jclepro.2020.125558.

22. Sandhu RK, Siddique R. Influence of rice husk ash (RHA) on the properties of self-compacting concrete: a review. Constr Build Mater. 2017;153:751-64. http://dx.doi.org/10.1016/j. conbuildmat.2017.07.165.

23. Tchakouté HK, Rüscher CH, Kong S, Kamseu E, Leonelli C. Geopolymer binders from metakaolin using sodium waterglass from waste glass and rice husk ash as alternative activators: a comparative study. Constr Build Mater. 2016;114:276-89. http://dx.doi.org/10.1016/j.conbuildmat.2016.03.184.

24. Tchakouté HK, Rüscher CH, Kong S, Ranjbar N. Synthesis of sodium waterglass from white rice husk ash as an activator to produce metakaolin-based geopolymer cements. J Build Eng. 2016;6:252-61. http://dx.doi.org/10.1016/j.jobe.2016.04.007.

25. Bernal SA, Rodríguez ED, Mejia De Gutiérrez R, Provis JL, Delvasto S. Activation of metakaolin/slag blends using alkaline solutions based on chemically modified silica fume and rice husk ash. Waste Biomass Valoriz. 2012;3(1):99-108. http:// dx.doi.org/10.1007/s12649-011-9093-3 .

26. Bouzón N, Payá J, Borrachero MV, Soriano L, Tashima MM, Monzó J. Refluxed rice husk ash/ $\mathrm{NaOH}$ suspension for preparing alkali activated binders. Mater Lett. 2014;115:72-4. http:// dx.doi.org/10.1016/j.matlet.2013.10.001.

27. Mellado A, Catalán C, Bouzón N, Borrachero MV, Monzó JM, Payá J. Carbon footprint of geopolymeric mortar: study of the contribution of the alkaline activating solution and assessment of an alternative route. RSC Advances. 2014;4(45):23846-52. http://dx.doi.org/10.1039/C4RA03375B.

28. Mejía JM, Mejía de Gutiérrez R, Montes C. Rice husk ash and spent diatomaceous earth as a source of silica to fabricate a geopolymeric binary binder. J Clean Prod. 2016;118:133-9. http://dx.doi.org/10.1016/j.jclepro.2016.01.057.

29. Kamseu E, Beleuk à Moungam LM, Cannio M, Billong N, Chaysuwan D, Melo UC, et al. Substitution of sodium silicate with rice husk ash- $\mathrm{NaOH}$ solution in metakaolin based geopolymer cement concerning reduction in global warming. J Clean Prod. 2017;142:3050-60. http://dx.doi.org/10.1016/j. jclepro.2016.10.164.

30. Geraldo RH, Fernandes LFR, Camarini G. Water treatment sludge and rice husk ash to sustainable geopolymer production. J Clean Prod. 2017;149:146-55. http://dx.doi.org/10.1016/j. jclepro.2017.02.076.

31. Teixeira OG, Geraldo RH, da Silva FG, Gonçalves JP, Camarini G. Mortar type influence on mechanical performance of repaired reinforced concrete beams. Constr Build Mater. 2019;217:37283. http://dx.doi.org/10.1016/j.conbuildmat.2019.05.035.

32. Tong KT, Vinai R, Soutsos MN. Use of Vietnamese rice husk ash for the production of sodium silicate as the activator for alkali-activated binders. J Clean Prod. 2018;201:272-86. http:// dx.doi.org/10.1016/j.jclepro.2018.08.025.

33. Marvila MT, de Azevedo ARG, Vieira CMF. Reaction mechanisms of alkali-activated materials. IBRACON Struct Mater J. 2021;14(3):1-26. http://dx.doi.org/10.1590/S198341952021000300009.

34. Poon CS, Lam L, Kou SC, Wong YL, Wong R. Rate of pozzolanic reaction of metakaolin in high-performance cement pastes. Cement Concr Res. 2001;31(9):1301-6. http://dx.doi. org/10.1016/S0008-8846(01)00581-6.

35. Kriven WM, Bell JL, Mallicoat SW, Gordon M. Intrinsic microstructure and properties of metakaolin-based geoolymers. In: International Worshop on Geopolymer Binders: Interdependence of Composition, Structure and Properties; 2007; Weimar, Germany. Proceedings. Germany: Shaker; 2007. p. 71-86.

36. Rocha TS, Dias DP, França FCC, Guerra RRS, Marques LRCO. Metakaolin-based geopolymer mortars with different alkaline activators $\left(\mathrm{Na}^{+}\right.$and $\left.\mathrm{K}^{+}\right)$. Constr Build Mater. 2018;178:453-61. http://dx.doi.org/10.1016/j.conbuildmat.2018.05.172.

37. Rashad AM. Metakaolin as cementitious material: History, scours, production and composition: a comprehensive overview. Constr Build Mater. 2013;41:303-18. http://dx.doi.org/10.1016/j. conbuildmat.2012.12.001.

38. Darsanasiri AGND, Matalkah F, Ramli S, Al-Jalode K, Balachandra A, Soroushian P. Ternary alkali aluminosilicate cement based on rice husk ash, slag and coal fly ash. J Build Eng. 2018;19:36-41. http://dx.doi.org/10.1016/j.jobe.2018.04.020.

39. ABNT: Associação Brasileira de Normas Técnicas. ABNT NBR 16605: Portland cement and other powdered material: determination of the specific gravity. Rio de Janeiro: ABNT; 2017. 4 p.

40. ABNT: Associação Brasileira de Normas Técnicas. ABNT NBR 12127: gypsum for buildings: determination of physical properties of powder. Rio de Janeiro: ABNT; 2019. 6 p.

41. EMBRAPA: Empresa Brasileira de Pesquisa Agropecuária. Manual de métodos de análise de solo. 2. ed. Rio de Janeiro: EMBRAPA; 1997. 212 p.

42. ABNT: Associação Brasileira de Normas Técnicas. ABNT NBR 13276: mortars applied on walls and ceilings: determination of the consistence index. Rio de Janeiro: ABNT; 2016. 2 p.

43. ABNT: Associação Brasileira de Normas Técnicas. ABNT NBR 15961-2: structural masonry: concrete blocks part 2: execution and site control. Rio de Janeiro: ABNT; 2011. 35 p.

44. ABNT: Associação Brasileira de Normas Técnicas. ABNT NBR 13279: mortars applied on walls and ceilings: determination of the flexural and the compressive strength in the hardened stage. Rio de Janeiro: ABNT; 2005. 9 p.

45. ABNT: Associação Brasileira de Normas Técnicas. ABNT NBR 9779: mortar and hardened concrete: determination of water absorption by capillarity. Rio de Janeiro: ABNT; 2012. 3 p.

46. Vinai R, Soutsos M. Production of sodium silicate powder from waste glass cullet for alkali activation of alternative binders. Cement Concr Res. 2019;116:45-56. http://dx.doi.org/10.1016/j. cemconres.2018.11.008.

47. Gado RA, Hebda M, Lach M, Mikula J. Alkali activation of waste clay bricks: Influence of the silica modulus, $\mathrm{SiO}_{2} /$ $\mathrm{Na}_{2} \mathrm{O}, \mathrm{H}_{2} \mathrm{O} / \mathrm{Na}_{2} \mathrm{O}$ molar ratio, and liquid/solid ratio. Materials . 2020;13(2):383. http://dx.doi.org/10.3390/ma13020383.

48. Hardjito D, Wallah SE, Sumajouw DMJ, Rangan BV. Factors influencing the compressive strength of fly ash-based geopolymer concrete. Civ Eng Dimension [serial on the Internet]. 2004 [cited 2021 Aug 28];6(2):88-93. Available from: https://ced. petra.ac.id/index.php/civ/article/download/16116/16108

49. Fernandes IJ, Sánchez FAL, Jurado JR, Kieling AG, Rocha TLAC, Moraes CAM, et al. Physical, chemical and electric characterization of thermally treated rice husk ash and its potential application as ceramic raw material. Adv Powder Technol. 2017;28(4):1228-36. http://dx.doi.org/10.1016/j. apt.2017.02.009.

50. Pagliari L, Dapiaggi M, Pavese A, Francescon F. A kinetic study of the quartz-cristobalite phase transition. J Eur Ceram Soc. 2013;33(15-16):3403-10. http://dx.doi.org/10.1016/j. jeurceramsoc.2013.06.014

51. Bertolini L, Carsana M, Cassago D, Quadrio Curzio A, Collepardi M. MSWI ashes as mineral additions in concrete. Cement 
Concr Res. 2004;34(10):1899-906. http://dx.doi.org/10.1016/j. cemconres.2004.02.001.

52. Autef A, Joussein E, Gasgnier G, Rossignol S. Role of the silica source on the geopolymerization rate ALL or. J Non-Cryst Solids. 2012;358(21):2886-93. http://dx.doi.org/10.1016/j. jnoncrysol.2012.07.015.

53. Longhi MA, Rodríguez ED, Bernal SA, Provis JL, Kirchheim AP. Valorisation of a kaolin mining waste for the production of geopolymers. J Clean Prod. 2016;115:265-72. http://dx.doi. org/10.1016/j.jclepro.2015.12.011.

54. Sagoe-Crentsil K, Weng L. Dissolution processes, hydrolysis and condensation reactions during geopolymer synthesis: part II. High Si/A1 ratio systems. J Mater Sci. 2007;42(9):3007-14. http://dx.doi.org/10.1007/s10853-006-0818-9.

55. Luukkonen T, Abdollahnejad Z, Yliniemi J, Kinnunen P, Illikainen M. Comparison of alkali and silica sources in onepart alkali-activated blast furnace slag mortar. J Clean Prod. 2018;187:171-9. http://dx.doi.org/10.1016/j.jclepro.2018.03.202.

56. Silva PD, Sagoe-Crenstil K, Sirivivatnanon V. Kinetics of geopolymerization: role of $\mathrm{Al}_{2} \mathrm{O}_{3}$ and $\mathrm{SiO}_{2}$. Cement Concr Res. 2007;37(4):512-8. http://dx.doi.org/10.1016/j. cemconres.2007.01.003.

57. Çetintaş R, Soyer-Uzun S. Relations between structural characteristics and compressive strength in volcanic ash based one-part geopolymer systems. J Build Eng. 2018;20:130-6. http://dx.doi.org/10.1016/j.jobe.2018.07.011.

58. Duxson P, Provis JL, Lukey GC, Mallicoat SW, Kriven WM, Van Deventer JSJ. Understanding the relationship between geopolymer composition, microstructure and mechanical properties. Colloids Surf A Physicochem Eng Asp. 2005;269(13):47-58. http://dx.doi.org/10.1016/j.colsurfa.2005.06.060.

59. Maddalena R, Roberts JJ, Hamilton A. Can Portland cement be replaced by low-carbon alternative materials? A study on the thermal properties and carbon emissions of innovative cements. J Clean Prod. 2018;186:933-42. http://dx.doi.org/10.1016/j. jclepro.2018.02.138.

60. Cheng H, Lin KL, Cui R, Hwang CL, Chang YM, Cheng TW. The effects of $\mathrm{SiO}_{2} / \mathrm{Na}_{2} \mathrm{O}$ molar ratio on the characteristics of alkali-activated waste catalyst-metakaolin based geopolymers.
Constr Build Mater. 2015;95:710-20. http://dx.doi.org/10.1016/j. conbuildmat.2015.07.028.

61. Pavía S, Treacy E. A comparative study of the durability and behaviour of fat lime and feebly-hydraulic lime mortars. Mater Struct. 2007;39(3):391-8. http://dx.doi.org/10.1617/s11527005-9033-4.

62. Albitar M, Mohamed Ali MS, Visintin P, Drechsler M. Durability evaluation of geopolymer and conventional concretes. Constr Build Mater. 2017;136:374-85. http://dx.doi.org/10.1016/j. conbuildmat.2017.01.056.

63. Najafi Kani E, Allahverdi A, Provis JL. Efflorescence control in geopolymer binders based on natural pozzolan. Cement Concr Compos. 2012;34(1):25-33. http://dx.doi.org/10.1016/j. cemconcomp.2011.07.007.

64. Temuujin J, van Riessen A, Williams R. Influence of calcium compounds on the mechanical properties of fly ash geopolymer pastes. J Hazard Mater. 2009;167(1-3):82-8. http://dx.doi. org/10.1016/j.jhazmat.2008.12.121.

65. Longhi MA, Zhang Z, Rodríguez ED, Kirchheim AP, Wang H. Efflorescence of alkali-activated cements (geopolymers) and the impacts on material structures: a critical analysis. Front Mater. 2019;6:89. http://dx.doi.org/10.3389/fmats.2019.00089.

66. Alehyen S, Achouri MEL, Taibi M. Characterization, microstructure and properties of fly ash-based geopolymer. J Mater Environ Sci [serial on the Internet]. 2017 [cited 2021 Aug 28];8(5):1783-96. Available from: https://jmaterenvironsci.com/Document/vol8/ vol8_N5/190-JMES-2930-Alehyen.pdf

67. Hajimohammadi A, van Deventer JSJ. Characterisation of onepart geopolymer binders made from fly ash. Waste Biomass Valoriz. 2017;8(1):225-33. http://dx.doi.org/10.1007/s12649016-9582-5.

68. Ma C, Long G, Shi Y, Xie Y. Preparation of cleaner one-part geopolymer by investigating different types of commercial sodium metasilicate in China. J Clean Prod. 2018;201:636-47. http://dx.doi.org/10.1016/j.jclepro.2018.08.060.

69. Guo S, Ma C, Long G, Xie Y. Cleaner one-part geopolymer prepared by introducing fly ash sinking spherical beads: properties and geopolymerization mechanism. J Clean Prod. 2019;219:686-97. http://dx.doi.org/10.1016/j.jclepro.2019.02.116. 